\title{
The study of biologically active substances stability in Bur marigold herb during storage
}

\author{
(C) Natallia V. Karazhan \\ Department of Pharmacognosy with a Course of the Faculty of Continuing Education \\ and Retraining. Educational Establishment "Vitebsk State Order of Friendship \\ of Peoples Medical University”. Av. Frunze, 27. Vitebsk, 210009. Republic of Belarus. \\ Phone:+7 (375212)60-14-05.E-mail:natallia_karazhan@tut.by
}

Keywords: Bur marigold herb, polysaccharides, flavonoids, luteolin-O-7-glucoside, luteolin, storage.

\section{Abstract}

This work presents the results of studying the content variability of polysaccharides, flavonoids, luteolin-O-7-glucoside and luteolin in Bur marigold herb for 24 months of storage in whole and cut form in two types of packaging - paper bags and parchment bags, packed in cardboard boxes.

It was found that a change in the content by $5 \%$ of the initial content of the pharmacological marker recommended by the herbal medicines committee of the European Medical Agency, in Bur marigold herb, was observed for polysaccharides when it was stored in whole form in closed paper bags after 6 months, when it was stored in cut form months in closed parchment bags packed in cardboard boxes - after 9 months; for flavonoids, these periods were respectively 6 months and 3-6 months.

In Bur marigold herb stored in whole form for 24 months in closed paper bags, the content of polysaccharides is $79.80-85.58 \%$, flavonoids $-58.24-82.05 \%$, luteolin- $O-7$-glucoside $-44.54-70.60 \%$ of the initial, luteolin $-57.14-61.02 \%$ of the value determined after 12 months of storage. In Bur marigold herb stored in cut form for 24 months in closed parchment bags packed in cardboard boxes, the content of polysaccharides is $74.60-85.00 \%$, flavonoids $-55.87-77.98 \%$, luteolin- $O-7$-glucoside $-51.56-65.08 \%$ of the initial, luteolin $-44.99-54.82 \%$ of the value determined after 12 months of storage.

Thus, the preservation of flavonoids (total and individual components), the type of packaging used for storage, and Bur marigold herb size have a significant effect, these factors do not affect the variability of the polysaccharide content during storage.

\section{References}

[1] Z.A. Temerdashev, N.A. Frolova, T.G. Tsyupko, D.A. Chuprynina. Assessment of the stability of phenolic compounds and flavonoids in medicinal plants during storage. Chemistry of plant raw material. 2011. No.4. P.193-198. (russian)

[2] O.V. Trineeva, I.I. Safonova, E.F. Safonova, A.I. Slivkin. Determination of flavonoids and study of the influence of storage conditions on their content in Sea Buckthorn fruits by TLC. Sorption and chromatography processes. 2012. Vol.12. No.5. P.806-813. (russian)

[3] I.V. Belova, E.N. Grunina. Content of biologically active substances in the raw materials of Melissa oficinalis L. during storage. Mat. Int. scientific-practical Conf.: The current state, problems and prospects for the development of agricultural science. Yalta. 2019. P.19-21. DOI: 10.33952/09.09.2019.04.

[4] G. Franz, U. Feuerstein. Chemical stability of some model polysaccharides. Macromoleular Symposia. 1997. Vol.120. P.169-181. DOI: 10.1002/masy.19971200118.

[5] D. Heigl, G. Franz. Stability testing on typical flavonoid containing herbal drugs. Pharmazie. 2003. Vol.58. P.881-885.

[6] D.V. Moiseev. Investigation of stability of flavonoids of Rudbekia hirta flowers by stress-testing, accelerated testing and long term testing methods. Vestnik of pharmacy. 2016. Vol.73. No.3. P.47-53. (russian)

[7] N.N. Ismawaty, S.A. Tarmizi, E.A.E. Hasmah, E. Nurulnahar. Effect of storage on phytochemical contents of misai kucing (Orthosiphon stamineus Benth) leaves. J. Trop. Agric. and Fd. Sc. 2015. Vol.43. P.165-170.

[8] D.V. Moiseev. Change of active component content in above-ground parts of Hypericum perforatum (Hypericaceae) during storage. Rastitelnye resursy. 2015. No.3. P.435-443. (russian)

[9] W. Letchamo. Effect of storage temperatures and duration on the essential oil and flavonoids of Chamomile. Journal of Herbs. Spices \& Medicinal Plants. 1993. Vol.1. P.13-26. DOI: 10.1300/J044v01n03_03.

[10] State Pharmacopoeia of the Republic of Belarus. Edition II. Vol.2. Molodechno. 2016. (russian) 